This work is licensed under a Creative Commons Attribution 4.0 International License.

Ovaj rad dostupan je za upotrebu pod međunarodnom licencom Creative Commons Attribution 4.0.

https://doi.org/10.31820/f.33.1.5

Dolores Miškulin

\title{
KAZALIŠNE TEME TALIJANSKOGA DRAMSKOG GLUMIŠTA KROZ RIJEČKI TALIJANSKI TISAK 1900. - 1914.
}

\author{
dr. sc. Dolores Miškulin, Sveučilište u Rijeci, \\ Fakultet za menadžment u turizmu i ugostiteljstvu Opatija \\ doloresm@fthm.hr iD orcid.org/0000-0002-3367-5683
}

prethodno priopćenje UDK 792:050 >(497.5Rijeka=131.1)“1900/1914“ rukopis primljen: 24. veljače 2021; prihvaćen za tisak: 31. svibnja 2021.

Rijeka je zbog svog položaja i povijesnih zbivanja oduvijek bila mjesto dodira $i$ ispreplitanja različitih tradicija, kultura i jezika. U razdoblju od početka dvadesetoga stoljeća, pa do Prvoga svjetskog rata u toj je multikulturalnoj $i$ višejezičnoj sredini postojala bogata tiskarska tradicija, tako da se u navedenom razdoblju tiskalo čak 13 periodičnih publikacija na četiri jezika koja su tada bila u uporabi (hrvatskome, talijanskome, njemačkome i mađarskome), a na daskama njenih dvaju kazališta igrale su se kazališne predstave na četiri jezika. U navedenom razdoblju u Rijeci je gostovalo pedesetak talijanskih glumačkih družina s više od 950 dramskih predstava, što je za duhovna strujanja unutar njenog urbanog kulturnog života od posebnog značaja. Te su gostujuće glumačke družine ujedno odigrale značajnu ulogu u kazališnome razvitku kao poveznices europskim kazališnim životom i šire, s tadašnjom kulturom u srednjoeuropskim razmjerima. Slijedom takvog razvoja situacije i sama se Rijeka našla u središtu civilizacijskog međudjelovanja različitih kulturnih tradicija, te je odigrala vrlo značajnu ulogu i kao posrednik između tadašnjeg hrvatskog, talijanskog, mađarskog i njemačkog kulturnog kruga.

Vrijedna svjedočanstva o tome nalaze se u tadašnjem riječkom tisku talijanskog govornog izraza koji do sada nije bio dovoljno istražen. Želeći svojim skromnim prilogom doprinijeti cjelovitijoj slici riječkog kazališnog života toga doba i riječkog kulturnog identiteta, koristili smo napise iz pet riječkih talijanskih periodičnih publikacija (La Voce del Popolo, Il Popolo, 
La Bilancia, La Difesa $i$ La Giovine Fiume) kao izvornu dokumentaciju za analizu kazališnih tema vezanih uz talijanski segment riječkog dramskog glumišta. Namjera nam je bila da kroz književno - kritičku analizu kazališnih osvrta $i$ kritike u dostupnim periodičnim publikacijama oslikamo stanje riječkog talijanskog dramskog glumišta kao značajnog čimbenika unutar riječkoga kulturnog identiteta, te doprinesemo njegovoj prepoznatljivosti u međunarodnom kontekstu.

Ključne riječi: kazališne teme; periodične publikacije; kazališna kritika; talijansko dramsko glumište; multikulturalnost; riječki kulturni identitet

\section{Uvod}

U ovom ćemo se radu osvrnuti na kazališne teme u pet riječkih periodičnih publikacija na talijanskome jeziku u kojima smo naišli na kazališne rubrike s prilozima o dramskom repertoaru gostujućih talijanskih glumačkih družina, kako bismo pomoću njih pokušali upotpuniti mozaik koji ocrtava obrise talijanskog segmenta riječkog kazališnog života toga razdoblja. Radi se o publikacijama La Voce del Popolo, Il Popolo, La Bilancia, La Difesa i La Giovine Fiume.

Kroz kulturološku i književno-kritičku analizu priloga o kazališnim temama u tim publikacijama, pokušat ćemo ustanoviti značajke kazališnog repertoara tog vremena, odjek kazališnih djela na publiku/gledateljstvo, ustanoviti kakav je utjecaj dramskih predstava na izgrađivanje kazališnog ukusa gledateljstva, te uočava li se, i u kolikoj mjeri, razvoj riječke talijanske kazališne kritike u periodičnim publikacijama koje čine korpus istraživanja.

Nije nam namjera rezimirati kronologiju gostovanja talijanskih glumačkih družina u Rijeci budući da su to u literaturi već poznate činjenice, ${ }^{1}$ već nam je želja da svojim osobnim viđenjem iz građe dosad neobrađenih periodičnih publikacija bar djelimice upotpunimo praznine koje smo zamijetili u vrlo oskudnoj literaturi o riječkoj kazališnoj tematici s početka dvadesetoga stoljeća. Kroz analizu napisa o talijanskom segmentu riječkog dramskog glumišta težnja nam je doprinijeti cjelovitijoj slici o ukupnom riječkom kazališnom životu u sklopu riječkog kulturnog identiteta,

1 Fabrio, Nedjeljko (1987) „Talijansko dramsko glumište na Rijeci u doba Hrvatske Moderne", Kazalištarije, Teatrologijska biblioteka, knjiga 19, Hrvatsko društvo kazališnih kritičara i teatrologa, Zagreb, 125-164. 
te slijedom toga pružiti skromni doprinos hrvatsko-talijanskim književno-kazališnim dodirima. ${ }^{2}$

Vremenski okvir istraživanja obuhvaća razdoblje od 1900. god. koja se u riječkoj književnoj povijesti, zbog retardacijskih pojava ${ }^{3}$, može uvjetno smatrati početkom riječke književne Moderne ili talijanskom terminologijom Dekadentizma, pa do samog početka Prvog svjetskog rata, odnosno 1913. kada su se kazališne aktivnosti privremeno prekinule.

Zbog specifične situacije u kojoj se Rijeka našla nakon Hrvatsko-ugarske nagodbe od 1868., Rijeka je proglašena posebnim državno-pravnim provizorijem (tzv. Corpusom separatumom), autonomnom oblašću koja ne potpada ni pod Ugarsku, ni pod Hrvatsku. ${ }^{4}$ Ta je situacija za Rijeku rezultirala nizom pogodnosti na izdavačkom i kulturnom planu. U to doba Rijeka je bila višejezična i multikulturalna sredina, budući da su osim Hrvata koji su naseljavali i obližnji Sušak, te Talijana, tu živjeli i Slovenci, Mađari, Židovi, Nijemci i Česi.

Premda je kulturna razina prosječnog stanovništva bila relativno nis$\mathrm{ka}^{5}$, u gradu koji je tada brojio pedesetak tisuća stanovnika, u razdoblju između 1907. i 1910. (koje ujedno predstavlja i doba najvećeg procvata periodike u Rijeci), tiskalo se čak 13 periodičnih publikacija od kojih 9 na talijanskom jeziku, te po dvije na hrvatskom i mađarskom jeziku. ${ }^{6}$ Taj nam je podatak bitan kad znamo da periodične publikacije predstavljaju osebujnu publicističku vrstu relativno novijeg datuma, koja kao ogledalo javnoga, pa i privatnog života ${ }^{7}$ predstavlja izvorni dokument za interpretaciju određenog povijesnog trenutka i svjetonazora.

Ne smijemo previdjeti činjenicu da su novine i časopisi, u povijesnom razdoblju koje razmatramo, predstavljali vrlo značajan, a u nekim slučajevima i jedini izvor informacija, odnosno kulturne komunikacije, za slabo ili

2 Čale, Frano (1968.) „O književnim i kazališnim dodirima hrvatsko - talijanskim”, Matica hrvatska, Dubrovnik.

3 Pužar, Aljoša (1999.) Città di carta / Papirnati grad, Edit, Rijeka.

4 Čulinović, Ferdo (1953) ,"Rijeka u državnopravnom pogledu“, Zbornik Rijeka.

5 Lukežić, Irvin (1993) „Gemma Harasim, Riječka pisma”, Fluminensia, god. 5, 1993, br. 1-2, str. 1-12.

6 Čak i danas periodične publikacije toga vremena predstavljaju gotovo jedini autentični izvor dokumentacije o našoj temi, međutim zbog činjenice da neki riječki talijanski dnevnici nisu sačuvani ili su tek dijelom sačuvani, jedan značajan izvor podataka o riječkom kazališnom životu nažalost je nepovratno izgubljen.

7 Cfr. Hergešić, Ivo (1936), Hrvatske novine i časopisi do 1848., Zagreb 
gotovo neobrazovanu širu čitalačku publiku. Kod riječke publike toga doba tisak je odigrao nadasve prosvjetiteljsku ulogu, a Rijeka je postepeno stekla brojnu i slojevitu, izbirljivu i zahtjevnu čitalačku i kazališnu publiku s razvijenom kritičkom sviješću.

Za duhovna strujanja unutar riječkog urbanog kulturnog života od posebnog je značaja talijansko dramsko glumište i bujanje kazališnog života u tom razdoblju. Budući da Rijeka do 1913. nije imala domicilni kazališni ansambl, u Rijeku su u to doba talijanske putujuće družine donosile svu dramsku kazališnu umjetnost tadašnje Kraljevine Italije. Značajan je podatak da je u razdoblju koje proučavamo u Rijeci gostovalo pedesetak talijanskih glumačkih družina s više od 950 dramskih predstava. ${ }^{8} \mathrm{Na}$ daskama dvaju riječkih kazališta igrale su se kazališne predstave na četiri jezika i sva su gostovanja značajnih imena ostala zabilježena u dnevnom tisku. Profesionalne družine s glumcima svjetskoga glasa kao prenositelji kazališne kulture odigrale su vrlo značajnu kulturnu funkciju u sklopu cjelokupnog kulturnog života Rijeke.

Kolumbić napominje da bez obzira na kvalitetu glume i izvedbe općenito, upravo pod utjecajem tih predstava u hrvatskim se primorskim gradovima počela razvijati stanovita kulturna navika, počela se izgrađivati i odgajati kazališna publika, a s vremenom i njezin sve osjetljiviji ukus. S razvojem osjećaja za kvalitetu scenskog doživljaja razvija se i kazališna kritika koja je bila povezana sa sve učestalijom pojavom časopisa i novina. ${ }^{9}$

Za razliku od tadašnjih hrvatskih dramatičara i kazališnih reformatora među kojima je vladalo veliko zanimanje za talijansku dramsku produkciju koja se nudila na riječkoj sceni, sa strane naših znanstvenika na području književnosti, povjesničara umjetnosti i teatrologa potpuno je izostao interes za sustavnu znanstvenu obradu i prosudbu postojećih svjedočanstava iz vrijedne građe periodičnih publikacija. Ovaj je rad ujedno i pokušaj da se na svijetlo dana iznesu neke činjenice i podaci i koji su već dugo neiskorišteno ležali među izblijedjelim stranicama starih riječkih talijanskih časopisa.

8 Čale, Frano (1968) „O književnim i kazališnim dodirima hrvatsko-talijanskim”, Matica hrvatska, Dubrovnik.

9 Kolumbić, Nikica (1990/1991) „Talijanski teatar na hrvatskoj jadranskoj obali u XIX. st.", Razdio filoloških znanosti 20, 1990/1991, str. 178. 


\section{Riječka talijanska kazališna kritika}

Napisi riječke talijanske kazališne kritike između 1900. i 1914. u tisku u početku se zapravo ne mogu smatrati pravim kritičkim osvrtima. Uglavnom su to najave o predstavama kojima se želi privući publika, te kraći napisi u kojima se prepričavaju sadržaji kazališnih komada i gotovo uvijek pozitivno komentira glumu glavnih glumaca, velikodušno dijeleći pohvale na račun velikana dramskog glumišta. Međutim, budući da zbog nedostatka pouzdanih pisanih izvora i gubitka građe talijanskih periodičnih publikacija ti zapisi predstavljaju jedina sačuvana svjedočanstva o tadašnjem kazališnom životu, ti su nam zapisi vrlo dragocjeni elementi putem kojih možemo rekonstruirati talijanski segment kazališnog života toga doba $u$ Rijeci. Za potrebe našeg rada razmotrit ćemo kronološkim redoslijedom njihovog pojavljivanja kritičke osvrte u pet riječkih talijanskih periodičkih publikacija tog vremenskog razdoblja: La Difesa, La Voce del Popolo, Il Popolo, La Bilancia i La Giovine Fiume.

Prvi kritički osvrt na dramsko djelo izvedeno u riječkom kazalištu nalazimo u broju 15 lista La Difesa od 17. 6. 1900. gdje se u rubrici „Notizie artistiche e teatrali" pojavljuje članak koji donosi sadržaj tada vrlo poznate predstave Come le foglie (Poput lišća) Giuseppea Giacose. U drami se prikazuje moralno rasulo obitelji propalog industrijalca, te scenski oživljava likove majke, sina - bezvoljnog rasipnika, te kćeri koja svojim samoubojstvom pokušava umanjiti sramotu obiteljske propasti. Vrijedni i radišni otac pokušava spasiti kćer povjerivši je nadobudnom mladiću, predstavniku pozitivnih ideala građanstva koji se pojavljuje na kraju drame da razriješi zaplet.

Osim sažetka dramske radnje, kritičar se osvrće i na ostale komponente koji doprinose cjelovitosti scenskoga dojma:

Ganutost osjećajima iz posljednjeg čina uvečana je i pojačana neizmjerno istančanim prikazom okoline, znalačkim ocrtavanjem psiholoških profila likova koja čine dramu. Giacosino djelo je sjajno $i$ stoga što nas navodi na razmišljanje $i$ analizu, a istinska umjetnost je ona koja pokazuje ljepotu majstorskim dodirom $i$ koja vodi um koji sudi do najviših vrhova misli.

Zbog tako sjajnog odjeka drame i uredništvo lista se oglasilo o tom velikom umjetničkom djelu u svom komentaru: 
'Poput lišća' je nesumnjivo moćno, veliko umjetničko djelo, koje se ističe prije svega vrlo plemenitom tendencijom reforme modernog kazališta, isuviše kontaminiranog pochadama svake vrste, zasjenjeno nordijskim maglama, koji se odlikuje iskrenošću vizije $i$ jasnoćom misli, ljepotom dijaloga, istinskim likovima punim vitalnosti, svježinom moderne satire koja kroz odgojni pristup ujedno oplemenjuje, kao i po živosti scene, te za izrazito ljudskoj $i$ pjesničkoj obojanosti. Unatoč tim svojstvima, međutim, još ne bih mogao potvrditi zaslužuje li 'Poput lišća' da se nazove remek-djelom slavnog komediografa, uzmemo li u obzir njegove 'Tužne ljubavi'.

U svakom slučaju, uspjeh 'Poput lišća' u Rijeci bio je, i to s pravom, velik $i$ iskren $i$ smatramo svojom dužnošću preporučiti svima koji vole uzvišena uživanja srca i uma da odu i čuju sljedeće reprize tog moćnog djela, vjerujte, jer gledanje predstave 'Poput lišća' u kazalištu vrijedno je više od čitanja stotinu knjiga o moralu $i$ studija o društvenom životu!

Autor osvrta se, kako zamjećujemo, vrlo kritički izražava o modernom repertoaru kojeg su, po njegovom mišljenju zagadile pochade ${ }^{10}$ ili pak zasjenile nordijske magle. O glumačkoj izvedbi i glumcima izazito će se pohvalno izraziti:

Izvedba 'Poput lišća' je bila izvrsna, posebice ona gospođe Vitaliani, koja je, ne oslanjajući se tek na scenske efekte geste i mimike, oblikovala i obojila svoju dikciju neusporedivom umjetnošću, učinila da njen glas kćeri i sestre zazvuči tako da gledatelja toliko duboko gane da posebno u IV. činu on teško može suzdržati suze koje su $\mathrm{mu}$, protiv njegove volje, poput bisera rosile trepavice.

Zbog tako pohvalnih kritika koje je predstava izazvala u Rijeci, zanimljivo je vidjeti kako je ista predstava doživjela sasvim oprečnu sudbinu prilikom svog uprizorenja u Rimu. U istome broju komentar izlazi pod efektnim naslovom Come le foglie caduta a Roma (Poput lišća pala u Rimu):

10 Nedjeljko Fabrio u članku „Talijansko dramsko glumište u Rijeci u doba hrvatske moderne” navodi da su pochade „....one tipične pariške komedije, briljantne, bučne i brbljave, koje su u Italiji, pa stoga i u riječkom talijanskom tisku zvali pochade. Sve do pred Prvi svjetski rat riječka je publika gladna pochada i gostujuće ih glumačke družine naprosto moraju stavljati na repertoar." (Fabrio, Nedjeljko, 1987, str. 306) 
Nevjerojatna je vijest da je snažna Giacosina komedija pala u Rimu. Rimska kritika želi srušiti to djelo ocijenivši ga tek osrednjim kao i Zacchonijevu izvedbu koja je u Trstu upravo tim djelom izazvala dugotrajan pljesak. 'Il Messaggero' kaže da je radnja potpuno promašena; 'Il Giorno' da je komedija ispod prosjeka; 'Tribuna' da je to bilo razočaranje i tako dalje. Ponavljamo, čini nam se gotovo nevjerojatnim da je u Rimu, u glavnom gradu Italije, moćno djelo, koje su jako doživjeli i oni manje inteligentni, moglo imati tako nepovoljan rezultat.

Autor nikako ne može shvatiti razlog zašto je tako izvrsna predstava koja je u Rijeci primljena s ushićenjem, u Rimu pak doživjela fijasko. Na koncu s nevjericom zaključuje da se među kritičarima zasigurno radilo o užarenim glavama ili čudacima kakvih ima, doduše u malom broju, i na riječkim ulicama. Nevjerica s kojom riječki kritičar prima vijest o negativnoj kazališnoj kritici u Rimu djeluje nam, s vremenskim odmakom, pomalo naivno i smiješno budući da će, kako ćemo vidjeti u nastavku, osvrti riječkih kazališnih kritičara toga doba, za razliku od europskih kolega, biti uglavnom pohvalni i blagi, ne toliko kritike na djelo i njegovu izvedbu, već prepričavanje sadržaja djela, glume i odjeka kod publike.

Sljedeći prilog nalazimo u listu La Voce del Popolo koji donosi osvrte kazališnih predstava u rubrici «Nei campi dell’Arte». Prvi kritički osvrt nalazimo u broju 4218 od 4. 7. 1901. Radi se o petočinki Le grandi manovre (Veliki manevri) u obradi A. Morolina:

Briljantna komedija Guerra in tempo di pace (Rat u doba mira) koju je znalački obradio Morolin pod naslovom Veliki manevri nije mogla biti uspješnije uprizorena nego što su to jučer učinili dramski umjetnici vrlo dobre družine Zago i Privato. Ne treba nikoga od njih posebno istaknuti ili pokuditi jer su se svi učesnici, od prvog do zadnjeg, nadmetali u umijeću, a oduševljena publika davala je naslutiti da će tražiti još jednu izvedbu ... a tko nije bio nazočan jučer, neka ode danas pa će nam dati za pravo.

Za međusobne odnose između kazališnih kultura dvaju naroda i prožimanje dviju kulturnih sfera značajno je istaći da je ponekad, doduše u vrlo malom broju slučajeva, talijanska kazališna kritika pratila i zbivanja na hrvatskome glumištu na tadašnjem Sušaku. Gotovo svi kazališni osvrti te vrste, osim šturih osvrta u listu Corriere, objavljeni su u dnevniku La Voce 
del Popolo u listopadu 1901. Tako broj 4317 od 9. 10. 1901. donosi prvi osvrt na djelatnost kazališne družine Petra Ćirića. Dan kasnije isti list donosi višestruko značajnu kritiku o Balkanskoj Carici Nikole Crnogorskoga. U broju od 11. listopada La Voce del popolo donosi kritiku o popularnoj komediji Šokica. Četvrti napis u svezi s nama nepoznatim komadom iz seljačkog života pojavljuje se u istom dnevniku od 13. listopada 1901., a peti napis o drami Graničari nosi nadnevak 14. listopada 1901.

U broju od 16. listopada 1901. list bilježi izvedbu tragedije Posljednji Zrinski Higina Dragošića uz brojno gledateljstvo i velik broj odličnika. Sljedeći broj od 17. listopada komentira izvedbu Djevojačke kletve. Tek uzgredno 17. listopada 1901. list bilježi izvedbe komada Madame Sans-Gêne Sardoua-Moreaua, te Starog kaplara Simona od Chiossonea, naglašavajući da su glumci uspješno položili za njih i te kako težak ispit. Posljednji napis u istom dnevniku nosi nadnevak 18. listopada 1901., a radi se o kritičkom osvrtu na romantičnu Dumanoireovu dramu Don Cezar od Bazana.

U srpnju 1902. u grad dolazi gostujuća družina Vittorine Duse s nizom vrlo uspješnih predstava poput Odette (Sardoua) ili veličanstvene drame u 6 činova i 7 slika R. Rindija i V. Salvonija I figli di nessuno (Ničija djeca). Koliko je ta drama bila značajna govori nam činjenica da su kao najavu urednici u broju 4588 od 12. 7. 1902. prenijeli kritiku iz jednog (nenavedenog) talijanskog lista:

'Ničija djeca' je senzacionalna drama čija tema ima dodirnih točaka s drugima koji su na scenu donijeli tužnu sudbinu zapuštene djece ... Autori Rindi i Salvoni na tome su radili s moralnim kriterijem, očito usmjerenim na društvenu kritiku; znalački su radili na umjetničkom izričaju, ali previše se držeći scenarija stare škole, te nisu znali ili nisu željeli izbjeći efektne završetke činova kroz nagle obrate radnje i već otrcane fraze. Ali rad ima i drugih prednosti, kako u situacijama tako i u ocrtavanju likova, te u homogenosti cjeline .... Određene progresivne $i$ društvene aluzije bile su zamijećene i dobro prihvaćene.

Usporedbom ove talijanske kritike s osvrtima riječkih talijanskih kritičara možemo ustanoviti koliko je potonja po formi, sadržaju, ali i kritičkom dosegu odstupala od sličnih uradaka u svjetskim razmjerima. Riječka je kazališna kritika, naime, tek u povojima, te usprkos vrijednih pokušaja, zaostaje ne uspijevajući još uhvatiti korak s europskim ostvarenjima na tom planu. 
U riječkom listu Il Popolo tijekom 1902. počinje izlaziti kazališna rubrika pod nazivom „Teatri, concerti e trattenimenti” koja prati kulturna i društvena zbivanja. Na prve kazališne teme u dnevnom listu La Bilancia nailazimo tijekom 1903. Rubrika „Teatro Fenice” koja prati događanja u istoimenom kazalištu, donosi niz zanimljivih vijesti koje još uvijek nisu kazališne kritike, već nam dočaravaju kazališni repertoar, izvedbe djela, glumu i odaziv publike na takva događanja, te odjek predstave.

U broju 4914 od 7. 6. 1903. saznajemo o velikom uspjehu kojeg je Giacosina predstava Trionfo d'amore (Trijumf ljubavi), polučila kod pubike. Autor napisa komentira događaj na sljedeći način: 'Trijumf ljubavi', srednjovjekovna Giacosina drama, uvijek prenosi svoj šarm pjesničkim dušama, te je i sinoć izazvala najveći interes i najviše emocija. Kritičar u nastavku hvali genijalnu izvedbu glumaca.

\section{Odjeci djela suvremenih riječkih dramatičara talijanskog jezičnog izraza}

Od suvremenih talijanskih riječkih dramatičara čiji se odjeci nalaze u tadašnjem tisku možemo nabrojiti djela Danielea Pillepicha, Basilia Marassija i Gina Antonya. Daniele Pillepich je jedan od prvih glasnika riječkog tzv. kulturalnog iredentizma. Svoje uglavnom ljubavne rime objavljivao je pod različitim pseudonimima: Renato Adriani, Daniele ili Daniele Filippi u tadašnjim časopisima Varietà, te Studio e lavoro. ${ }^{11}$ Autor je autor stihovane komične crtice Fede, speranza e carità!, (Vjera, nada i milosrđe!) koju je 2. srpnja 1900. izvela Compagnia drammatica Italia Vitaliani. O tom djelu ne zna se mnogo već samo to da dnevnik «La Voce del Popolo» od 3. srpnja 1900. donosi o njemu vrlo šturu napomenu: Riječ je o skromnoj stvarčici koja obuhvaća nekoliko stihovanih prizora.

Basilio Marassi napisao je jednočinku s temom iz rata za nezavisnost pod nazivom Anita. Izvedena je 30. listopada 1909. sa strane Società filarmonico-drammatica. Djelo je pisano za četiri osobe, a iz kritičkog prikaza u listu La giovine Fiume od 6. 11. 1909. saznajemo da je to bio vrlo kratak sastavak, bez zahtjeva. Izveli su ga riječki dramski amateri.

11 Miškulin, Dolores (2019) „Književne teme u riječkoj periodici na talijanskome jeziku 1900. - 1919., FMTU, Opatija. 
Gino Antony ${ }^{12}$ je najznačajniji riječki dramski pisac, a njegova komedija u četiri čina pod nazivom Eroi senza gloria (Junaci bez slave) koju je 12. prosinca 1904. izvela «Drammatica compagnia italiana di Ettore Berti», tako je dobro prihvaćena u publici, da je autor osam puta izlazio pred zastor. Iz prikaza u listu «La Voce del popolo» od 13. prosinca 1904. možemo razabrati sadržaj drame. ${ }^{13} \mathrm{Za}$ današnje prilike vrlo naivna drama, prilično neuvjerljiva zapleta i još neuvjerljivijeg raspleta, ipak se, kako vidimo, vrlo pozitivno dojmila publike. U ovom je slučaju čak i kritika pozitivno reagirala. Naime, u kritičkom je prikazu navedeno: Komad 'Junaci bez slave' nije ama baš ništa lošiji od premnogih 'dramskih noviteta' što su nam ih za protekle kazališne sezone izveli glumačke družine Mariani i Caimmi.

Sljedeću dramu u tri čina pod nazivom Poveri illusi (Obmanuti jadnici) 1. srpnja 1905. izvela je družina «Compagnia drammatica Giulia Iris e Ignazio Mascalchi», a iz tiska saznajemo da je polučila gotovo isto tako mnogo uspjeha kod publike. Iz dnevnika «Il Popolo» br. 988 od 1. 7. 1905. saznajemo okvirni sadržaj drame. ${ }^{14}$ Autor kritičkog prikaza pohvalno se izrazio o formalim obilježjima djela. Što se tiče izvedbe, hvalevrijednom se

12 Usp. Miškulin, Dolores (2013) Pregled stvaralačkog opusa riječkog pisca Gina Antonija (Cavaliere di Garbo) kroz presjek riječkoga tiska na talijanskom jeziku, Fluminensia, god. 25/2013, br. 2, 7-20.

13 Barun Dario Bellani prisiljen je napustiti časničku dužnost u talijanskoj mornarici, te uzdržavati majku i sestru Rosu nakon što je njegov otac zbog financijskog kraha počinio samoubojstvo. Darijev brat Paolo i njegova rasipna djevojka Giustina nemilice rasipaju skromni ostatak obiteljskog imutka, te se čak i zadužuju u Parizu, zbog čega će konačno i Paolo hiniti pokušaj samoubojstva. Nezavidnu financijsku situaciju na opću radost razrješava Darijev prijatelj Mastilli koji mu nalazi bogatu udavaču i time, nakon svečanog vjenčanja, izvlači obitelj iz krize.

14 Radnja se zbiva u Genovi. Glavni lik, Claudio Morisani, bio je tijekom dvadeset godina direktor Lloyda u Genovi, ali ga sad zainteresirani brodski dobavljači smjenjuju jer na njegovo mjesto žele postaviti njima prikladniju osobu. Smjenjivanje Claudia s dužnosti izaziva lom u obitelji: njegovu kćerku Nerinu napušta zaručnik koji se nadao da će naslijediti Cludijev položaj, dok Claudijev sin Enrico, koji se zbog imutka oženio bogatom Amerikankom, javno izjavljuje da se stidi vlastita oca. U nevolji Morisaniju ostaju dva jedina prijatelja: kapetan Lowe i skladatelj Palma, još jedan obmanuti lik, koji se izdržava privatnim lekcijama glasovira, budući da je operu koju je on komponirao netko uspio plagirati, te se sad uspješno prikazuje na scenama. Nakon što otkriva zaručnikove namjere Nerina ga tjera od sebe, te uz pomoć maestra Palme počinje davati satove glasovira. Čak i sin Enrico pokušava se naknadno približiti ocu nudeći mu novčanu pomoć, ali ponosni Claudio to odbija želeći sam pronaći novi posao kod različitih tvrtki. Napokon se u drami pojavljuje jedan inženjer iz Čilea, Claudijev nekadašnji dužnik, koji nudi Claudiju direktorski posao u jednoj od svojih tvornica, te naposlijetku sklapa brak s njegovom 
pokazala gluma svih izvođača: Mascalchi (koji je igrao Morisanija) je vrlo uspješno izrazio psihološki portret glavnog lika, dok je glumica Iris bila vrlo uvjerljiva u ljubavnoj sceni - završnoj sceni drugog čina, te ju je publika dva puta nagradila pljeskom na otvorenoj sceni. I ostali su se glumci iskazali vrsnoćom u svojim ulogama (Falcini kao Lowe, Molinari i Lupi). Scenogafija je bila vrlo uspješna i zapažena. Dnevnik La Voce del popolo u br. 5658 od 1. 7. 1905. navodi pouku ovoga komada koju navodno izgovara u trećem činu stari Morisani: Sretan je onaj koji se dade obmanuti. Dakle, sam naziv drame (Obmanuti jadnici) u sebi nosi dominantne naznake: obmana, obmanjeni i sam jad vezan uz tu pojavu. Autor kritičkog prikaza zamjera djelu višak konvencionalnosti i romantičnosti koji su, po njemu, primjereniji kakvom salonu negoli pozornici.

Jednočinku Prva i zadnja (La prima e l'ultima) 8. srpnja 1905. izveli su amateri, članovi dramske sekcije riječkoga Glazbeno-dramskog društva (sezione drammatica della Società filarmonico-drammatica) uz pomoć i nastup glumačke družine "Iris-Mascalchi». O djelu se ne zna gotovo ništa, izuzev da ga «Il Popolo» u broju 995 od 8. 7. 1905. naziva «djelcem».

Antonyjevo djelo Aria nuova (Novi vjetar) izvela je tijekom svog gostovanja dramska družina Ettore Berti 11. prosinca 1905., nakon što ga je družina Caimmi-Zoncada bila uvrstila a svoj repertoar u Milanu. Iz intervjua kojeg je autor povodom premijere dao listu La Voce del popolo u br. 5814 od 4. 12. 1905. saznajemo da se zbog socijalno-političke aktualnosti radnje koja je bila smještena u prostorima talijanskog javnog života, ocijenilo da je djelo nekako isuviše nabijeno elektricitetom za milansko gledateljstvo u kojem se gradu i odvija dio drame. Zato se praizvedba umjesto u Milanu održana u Torinu, te je u izvedbi Glumačke družine Ettorea Bertija obišla Italiju i nakon Trsta došla i u Rijeku. Igrom slučaja, dakle, Glumačka družina Ettorea Bertija uprizorila je dva dramska djela Gina Antonyja.

Za razliku od ostalih, potonje djelo nije naišlo na veliku popularnost kod publike ni kod kritike. Iz lista La Voce del popolo br. 5821 od 12. 12. 1905. saznajemo nešto o sadržaju te drame. ${ }^{15}$ Međutim dnevnik Il popolo u broju 1152 od 1905. ocijenio je ovo djelo uljudno, ali negativno.

kćerkom Nerinom. Nakon olujnih događaja koji su Claudiju pruzrokovali sijedu kosu, na obzoru se, dakle, napokon nazire mir i sklad, te se drama završava u takvom umirujućem tonu.

15 Novi vjetar dr. Gina Antonyja iznosi na pozornicu strujanje onih ideja koje se u naše vrijeme nalaze vrlo često u proturječju između njih samih, a često puta takve ideje potiru jedna drugu. Vlasnik svilane, Luciano Ascoli, primjer je starca starinskoga kova; borio se kod 
Za gostovanja družine Feruccio Benini 1906. trebao je biti izveden novi Antonyjev komad «Anime schiave» (Ropske duše), do čega međutim nije došlo. Ista je družina u Veneciji izvela njegova dva dijalektalna djela $E l$ ritorno i El zogo.

\section{Odjeci krize u talijanskom dramskom glumištu}

Prilikom gostovanja znamenite sugrađanke Irme Gramatiche u novinama La Voce del popolo broj 6189 od 21. 12. 1906. izašao je kritički prikaz u kojem se autor osvrće na razloge slabe posjećenosti kazališta: Gledateljstvo iz večeri u večer baš i ne hrli u kazalište, a mi smo na to prvi skrenuli pozornost. Ali pripisivati 'latinskoj kulturi' našega grada, kako to zlobno podmeće hrvatski dnevnik ${ }^{16} i$ kako to brzopleto i olako izjavljuju izvjesni pojedinci, posljedica je ili nepromišljenosti samoga suda ili jedostavno puke zlobe, ukoliko dakako posrijedi nisu neki posebni razlozi.

Nakon navođenja podataka iz intervjua kojeg je dramatičar Marco Praga dao milanskom listu Corriere della sera, a u kojem raščlanjuje dramatičnu financijsku situaciju talijanskih kazališta, tekstopisac zalazi u razloge loše posjećenosti teatra, te ih nalazi u lošoj kvaliteti glumačkih družina, njihovom slabom i necjelovitom sastavu, te prevelikom broju ne baš dobrih glumaca. Svim tim uzrocima slabog odaziva kazališnog gledateljstva tekstopisac kao specifikum riječke situacije dodaje po njemu pretjeranu skupoću kazališnih ulaznica, te kao rješenje nudi pristupačnije cijene ulaznica za kazališne predstave, a nadasve zagovara kvalitetnije i nadahnutije obavljanje glumačkog zanata.

Tijekom 1908. godine u kazališnoj rubrici lista La Bilancia vrlo je aktualna tema D’Annunzijeve nove drame La nave (Brod), pa joj se stoga

Custozze pa sad tješi svoju starost glazbom i obitelju, ne dopuštajući nikom da dirne u Domovinu. Njegov sin Artur je mladić posve suvremenih nazora: spletkari kako bi postao socijalistički poslanik, a u međuvremenu zavodi radnicu po imenu Angela. Njen brat Marcello Accorti voli Giacintu, kćerku staroga Ascolija, koja mu uzvraća ljubav. Razdor nastaje kada se ideje očeva i njihovih prijatelja sukobe s onima u glavama sinova i radnika. Najdramatični trenutak se zasniva na starčevom saznanju o opasnosti od štrajka, otkriću sinovljevih spletki, te otkrivenoj Giacintinoj ljubavnoj vezi. Starac se naposlijetku miri sa neminovnošću: «Izgubio sam jednu bitku», izjavljuje, "ali sam zato dobio tolike druge!» Drama se svečano zatvara uz zaključak da sav novi svijet nije posve izgubio vjeru u ideale domoljublja i plemenite osjećaje.

16 misli se na Novi list 
posvećuje osobita pozornost. ${ }^{17}$ Među predstavama koje je uprizorila „Compagnia Solari” najveću pozornost je privukla Oscar Wildeova Una donna qualunque (Obična žena) kod koje, međutim, kritičar u br. 152 od 8. 7. 1908. zapaža staromodnost: pretjerani romantizam fabule, konvencionalnost teze, te niza paradoksalnih situacija u kojima se engleski majstor iskazao i u privatnom životu slijedeći svoj tipično hedonistički, ali i pomodni dekadentistički motto užitka kao temeljnog životnog pokretača.

Društvena kriza u prvom desetljeću dvadesetog stoljeća zrcali se u svojevrsnoj teatarskoj krizi koju zamjećujemo kroz još jedan kazališni osvrt. List La giovine Fiume od 20. studenog 1909. svojim će člankom svjedočiti o toj krizi slijedećim tekstom: Glumačko družina Gemme Caimmi nije uvijek bila na razini svoje glumačke razglašenosti; tijekom više večeri morali smo zažaliti nad bezvoljnošću što je obuzela glumce kao i nad činjenicom da se tekst koji se ima govoriti zna slabo, što vrijedi čak i za tumače glavnih uloga!

Početkom 1911. kroz rubriku «Teatri ed Arte» u listu La Bilancia iz talijanskih se novina prenosi niz aktualnosti iz kazališnog života. Tako u br. 2 od 3. 1. 1911. nalazimo proglas Tommasa Salvinija «Contro il teatro immorale» iz Giornale d'Italia u kojem se autor poradi moralne edukacije naroda zalaže za instituciju 'teatri popolari' (pučka kazališta) u kojima bi se trebale predstavljati isključivo moralne, domoljubne i edukativne drame.

U osvrtu na Goldonijeva predstavu Il burbero benefico (Osorni dobročinitelj) kritičar u br. 101 od 4. 5. 1911. kaže: Publika je dobro prihvatila komediju, diveći se njezinim kvalitetama svježine i prirodnosti, te pljeskala Novelliju najiskrenijim oduševljenjem, pozivajući ga tri ili četiri puta na pozornicu na kraju svakog čina.

U broju 122 od 30. 5. 1911. u rubrici «Teatri ed Arte» izlazi osvrt «D’Annunzio, l' incompreso» (Neshvaćeni D’Annunzio) u br. 122 od 30. 5. 1911. saznajemo da je, kako ga autor članka naziva - «l'immaginifico», prilikom uprizorenja svog Svetog Sebastijana izjavio za pariški ‘Temps' da je u Italiji njegova umjetnost neshvaćena, te da će Talijani njen doseg moći shvatiti tek za sedamdesetak godina. Zaključak je kritičara: Takva izjava neshvaćenog pjesnika izazvala je u Italiji razumljivo ogorčenje. Međutim list 'Giornale d'Italia' istog trenutka proglašava D’Annunzija «Uno Stendhal alla

17 U nekoliko navrata izlaze napisi pod naslovima: „In attesa della 'Nave”, „Dalla Nave di Gabriele d'Annunzio” All'Adriatico, (br. 8 od 11. 1. 1908.), La prima della 'Nave' (br. 9 od 13. 1. 1908.). 
rovescia» (Obrnuti Stendhal) podsjećajući kako je potonji svojevremeno bio izjavio da se smatra Talijanom, budući da ga njegovi sunarodnjaci neće shvatiti ni pedeset godina nakon njegove smrti.

U rubrici «Arte e teatri» u br. 293 od 29. 12. 1911. nalazimo članak «Per la prossima rappresentazione del 'Chantecler' di Rostand», te članak „In attesa di Chantecler" sa skraćenim sadržajem komedije, ${ }^{18}$ a uskoro i u broju od 8. 1. 1911. kritika koju potpisuje A. de Schlemmer nakon riječke predstave, dakle gotovo 11 mjeseci prije njenog prvog uprizorenja u Kraljevini Italiji.

Prva u nizu predstava pompozno najavljivane Družine Ruggeri, Bernsteinov Sansone (Samson), bila je slabo posjećena i dobila je nepovoljnu kritiku pod naslovom „La prima della Compagnia Ruggeri“ u br. 112 od 20. 5. 1913.: to je radnja koja se temelji na epizodama od kojih je jedna paradoksalnija od druge, pa je čak i završetak neuvjerljiv. Kroz komentar sljedeće Kistermaeckersove drame La fiammata (Veliki plamen) u br. 113 od 21. 5. 1913. kritičar je sažeo osobine francuskog teatra i pohvalio dramu: Izlaganje nam se čini prenaglašenim, ali upravo to je mali nedostatak francuske škole; djelimice je to posljedica tema koje vrludaju od domovinskih dogadanja, do otkrića izdaja, financijskih krahova, sumnji u špijunažu; ali čak $i$ bez te osebujnosti, Kistermaeckersovo djelo posjeduje osobine koje ga čine dobrodošlim.

Pravo osvježenje i malu senzaciju izazvala je družina Sema Benellija s predstavama La Gorgona, ${ }^{19}$ povijesnom epizodom osvajačkog pohoda građana Pise iz XII. st. i antagonizma s Firencom, te Cena delle beffe (Bezdušna šala). Nakon toga u lipnju 1913. u grad pristiže dijalektalna "Compagnia comico-drammatica 'Città di Venezia'» koju vodi Alberto Brizzi. Publici su dijalektalna djela vrlo bliska, no ipak Goldoni još uvijek drži primat među autorima. Evo što kritičar kaže u br. 130 od 11. 6. 1913. u osvrtu na Goldonijeve I Rusteghi (Grubijani): ... komedija koja je uvijek živa, uvijek istinita, u kojoj se divimo univerzalnim likovima oslikanim majstorskom rukom, koje danas osjećamo i razumijemo onako kako su ih osjećali i razumjeli suvremenici velikog venecijanskog dramatičara.

Posljednja gostujuća dramska družina koja pohodi grad neposredno prije početka rata 1914. je „Compagnia Calabresi”. Međutim, iz lista La voce

\footnotetext{
18 Rubrika „Teatro Comunale” donosi članak „In attesa di Chantecler” (nella splendida versione italiana di L. Stecchetti ed A. Giaquinto, prevista per sabato 6 gennaio 1912 a Fiume). Predstava se prvi put davala 6. veljače 1910. u Parizu u kazalištu „Porte Saint Martin”, dok se u Italiji prvi put održala 5. prosinca 1911.
}

19 Prikaz u broju 121 od 31. 5. 1913. 
del popolo u br. 9958 od 16. 8. 1913. saznajemo izuzetno značajnu i dugo očekivanu novost za talijanski kulturni krug grada Rijeke: ona napokon dobiva svoju prvu talijansku glumačku družinu pod imenom Compagnia drammatica «Città di Fiume», a na njenom repertoaru će biti već prokušani dramski tekstovi: Ugo Ojettijev Il garofano (Karanfil), Giuseppe Giacosin Tristi amori (Sjetne ljubavi) $i$ jednočinka Ateone l'infanticida (Ateon čedomorac) nepoznatog autora.

\section{Zaključak}

Iz svega ranije navedenog možemo rezimirati da je novinska kazališna kritika u riječkim novinama La Voce del Popolo, Il Popolo, La Bilancia, La Difesa i La Giovine Fiume anonimna isto kao i redateljski rad, scenografija, kostimografija koji se nikad ne spominju, kao ni njihovi autori. Novinski kritički prikazi, međutim, uz didaktičku funkciju imaju i estetsku funkciju. Kroz njih dobivamo uvid u riječku kazališnu publiku toga vremena, njenu kazališnu kulturu, njen stav prema kazališnim predstavama, a kazališna kritika zrcali ukus i afinitete riječke publike, te utječe na njihov razvoj. Naime riječka je publika, po mišljenju riječkih kritičara, navikla na lagodan i elegantan tijek radnje talijanskih komedija, te ne prihvaća baš najbolje drugačije modele (kao npr. modernih moralnih tragedija), posebice misaonije ili poučne dramske tekstove kao što su to primjerice drame Henryja Bernsteina. Gledateljstvo preferira lagane komedije i vodvilje u kojima prevladavaju prpošne dosjetke i humor. Od autora najviše cijeni djela iz dijalektalne tradicije, posebice venecijanske. Vrlo postepeno riječka će kazališna publika naučiti sagledavati vrijednosti zahtjevnijih dramskih uradaka, a kazališna će kritika isto tako vrlo postupno i tek mnogo kasnije od anonimne polako prerastati u autorsku kritiku.

Analizom naslova sveukupnog dramskog repertoara talijanskih glumačkih družina u riječkim kazalištima Teatro Comunale (kasnije preimenovanog u Teatro Verdi) i Teatro Fenice u rasponu od početka stoljeća pa do 1914., te iz proučene literature zaključujemo da se većinom radilo o djelima tadašnjih suvremenih talijanskih dramatičara, zatim suvremenih i novijih francuskih dramatičara, pa tek onda europskim dramskim klasicima 18. st., starogrčkim tragičarima i talijanskim suvremenim riječkim dramatičarima. Pored toga, česta su bila gostovanja družina koje su izvodile djela jednog autora (npr. Compagnia benelliana), pa zatim dijalektalna djela, sicilijanska, pijemontska, ali naročito venecijanska, te je slijedom toga u 
Rijeci u navedenom razdoblju gostovalo čak sedam kazališnih družina venecijanskoga dijalekta.

Građanska veristička drama i komedija bila je najzastupjenija i najviše izvođena na daskama riječkih kazališta. ${ }^{20}$ Dijalektalno kazalište venecijanskog podneblja zastupali su Giacinto Gallina i Angelo Morolin. Prvi je zbog afiniteta publike, uz Goldonija, bio najizvođeniji talijanski komediograf, te su Riječani imali prilike vidjeti trinaest njegovih djela.

Što se tiče novijih i suvremenih talijanskih dramatičara možemo ustvrditi da repertoar seže do razdoblja kasnog romantizma. Uz to nalazimo predstavnike nove građanske drame, realističkog romantizma i verističkog kazališta i dekadentizma. Od najsuvremenijih pisaca tog razdoblja Riječani su mogli vidjeti djela Vincenza Morella, Renata Simonija, Sabatina Lopeza, Augusta Novellija, Uga Ojettija, te Darija Niccodema. Mnogo rjeđe su na repertoaru bila djela francuskih dramatičara, dramskih klasika XVIII.st., i dramatičara iz ostalih europskih zemalja. Od suvremenih talijanskih riječkih dramatičara zastupljena su djela Danielea Pillepicha, Basilia Marassija i najznačajnijeg riječkog dramskog pisca Gina Antonyja.

Za hrvatsko-talijanska kulturna prožimanja značajno je istaći da je ponekad talijanska kazališna kritika pratila i zbivanja na hrvatskom glumištu u Sušaku. Ti su osvrti objavljeni u listu Voce del popolo tijekom listopada 1901.

Riječka kazališna kritika na talijanskom jeziku između 1900. i 1914. izraz je svoje multikulturalne sredine, te mnoštva raznorodnih kulturnih utjecaja koji su je obogaćivali, dajući joj specifični pečat. Ona predstavlja svjedočanstvo o tadašnjem kazališnom životu i riječkom kulturnom identitetu toga doba. Zbog toga smo njene značajke nastojali istražiti i valorizirati, te budućim istraživačima ukazati na mogućnosti njene interpretacije.

\section{Literatura}

Čale, Frano (1968) „O književnim i kazališnim dodirima hrvatsko talijanskim“, Matica hrvatska, Dubrovnik.

Čulinović, Ferdo (1953) „Rijeka u državnopravnom pogledu“, Zbornik Rijeka.

20 Nju zastupaju Giuseppe Giacosa, Girolamo Rovetta, Marco Praga, Giannino Antona Traversi i Carlo Bertolazzi. 
Fabrio, Nedjeljko (1987) „Talijansko dramsko glumište na Rijeci u doba Hrvatske Moderne", Kazalištarije, Teatrologijska biblioteka, knjiga 19, Hrvatsko društvo kazališnih kritičara i teatrologa, Zagreb,125-164.

Hergešić, Ivo (1936) Hrvatske novine i časopisi do 1848., Zagreb.

Kolumbić, Nikica (1990/1991) “Talijanski teatar na hrvatskoj jadranskoj obali u XIX. st.", Razdio filoloških znanosti 20.

Lukežić, Irvin (1993) „Gemma Harasim, Riječka pisma”, Fluminensia, god. 5/1993, br. 1-2.

Miškulin, Dolores (2019) „Književne teme u riječkoj periodici na talijanskome jeziku 1900. - 1919., FMTU, Opatija.

Miškulin, Dolores (2013) Pregled stvaralačkog opusa riječkog pisca Gina Antonija (Cavaliere di Garbo) kroz presjek riječkoga tiska na talijanskom jeziku, Fluminensia, god. 25/2013, br. 2, 7-20.

Pužar, Aljoša (1999) Città di carta / Papirnati grad, Edit, Rijeka.

\section{Novine}

La Bilancia, 1867. - 1919.

La Voce del Popolo, 1889. - 1915./1922.

La Difesa, 1897. - 1901.

Il Popolo, 1902. - 1919.

La Giovine Fiume, 1907. - 1910. 
SUMMARY

Dolores Miškulin

ITALIAN DRAMA THEATER THEMES IN RIJEKA'S ITALIAN PRESS 1900-1914

Due to its position and historical events, Rijeka has always been a place of contact and intertwining of different traditions, cultures, and languages. During the period from the beginning of the $20^{\text {th }}$ century until the First World War, there was a rich publishing tradition in that multilingual and multicultural environment, and in that period as many as 13 periodicals were published in four languages that were then in use (Croatian, Italian, German, and Hungarian), and in Rijeka's two theaters, theatrical performances in four languages were given regularly. During this period, Rijeka hosted about fifty Italian acting troupes which delivered more than 950 performances, which is of special importance for the spiritual currents within its urban cultural life. These guest acting troupes also played a significant role in Rijeka's theatrical development as links with European theatrical life and beyond, with the culture of the time on a Central European scale. Following such a development, Rijeka found itself at the center of civilizational interaction of different cultural traditions and played a very important role as a mediator between Croatian, Italian, Hungarian and German cultural circles of that time.

Valuable evidence of this can be found in Rijeka's Italian periodicals, which have not been sufficiently researched so far. Wanting to contribute to a more complete picture of Rijeka's theatrical life of that time and Rijeka's cultural identity, we used articles from five of Rijeka's Italian periodicals (La Voce del Popolo, Il Popolo, La Bilancia, La Difesa and La Giovine Fiume) as original documentation for the analysis of theatrical themes related to the Italian segment of the Rijeka Drama Theater. Our intention was to complete the picture of the state of Rijeka's Italian drama theater as a significant factor within Rijeka's cultural identity, and to contribute to its recognizability in the international context through literary-critical analysis of theatrical reviews and critiques in available periodicals.

Key words: theatrical themes; periodicals; theater criticism; Italian drama theater; multiculturalism; Rijeka's cultural identity 